\title{
Political myths propagated by the Russian Federation in Ukraine
}

\section{Introduction}

"Never trust a Russian, because a Russian does not believe in even themselves"

The quote described above belongs to Otto von Bismarck, the German Chancellor ${ }^{2}$. It should be emphasized that Bismark had been living for several years in the Russian empire while being an ambassador from Prussia in this country. Otto von Bismarck spoke Russian well and according to Russians, he loved their country and "understood the essence of the Russian mentality"3.

Nowadays Otto von Bismarck's approach is current as never before. New technological possibilities and the readiness to spend large sums of money on propagandistic manipulation causes a real threat for the world community, especially for the neighbors of the Russian Federation such as Ukraine. "Informational aggression" by the current Kremlin authorities was clearly revealed at the end of winter, 2014. Making steps aimed to seize the sovereign territories of Ukraine, Russians tried to highlight the political and economic processes in Ukraine in a favorable light to reinforce their aggressive imperialistic policies. On the other hand, doing their best to destabilize Ukraine, Russians appealed "for peace" and offered the Ukrainians their "service" as a main intermediary between the new authority and the Donbass terrorists. It should be emphasized that in this case there is a unique situation when the main initiator and participant

The article was prepared during the scholarship in the framework of Iwan Wychowski Award.

2 Правила життя Отто Бісмарка, http://www.jnsm.com.ua/cgi-bin/m/pz.pl?ps=13, access: 1.04.2016.

3 Бисмарк о России и Украине, http://journal-otechestvo.ru/bismark-rossia-ukraina/, access: 6.08.2015. 
of a military conflict claims to be the intermediary, which is a kind of double-speak. The original involvement of the Russian authorities was evidenced by records of phone conversations of the Russian president's adviser Sergey Glazyev which were revealed by the Prosecutor General of Ukraine. It confirms that the aforementioned Russian official coordinated pro-Russian demonstrators, provided money for their meetings and instructed them how to act in order to enable a Russian invasion to Ukraine. According to the records, and in addition to the Donbass region, Russia was also interested in the Odessa Oblast, Kharkiv Oblast, Zaporizhia Oblast ${ }^{4}$.

\section{Russian Manipulation and the Response of the Leading Global Players}

In order to strengthen its global influence, the Russian government quite often acts according to the rules which are unacceptable in the civilized world and takes clear cheap shots. Quite often it happens that statements issued by the Russian authorities are not realized in practice at all. There are frequent situations when Kremlin officials act in an opposite way to the promises they have made. It is normal for Russian authorities to use propagandistic platitudes, manipulation with the facts and processes, and the possibility of which is hard to check and is time consuming.

Previous acts of the Russian Federation in the Middle East region serve as good illustration of similar kinds of bellicose activity. For example, it is worth mentioning the situation regarding statements by Kremlin authorities on the troop pullout from Syria. At the end of September in 2015, the Russian army commenced the bombing of Syrian territory and on February 12th, 2016, a ground campaign was initiated. Instead of this, three months later Vladimir Putin suddenly claimed that the performance targets of the Russian military in Syria were "altogether completed" and the terms for "the beginning of a peace process" were created. Hence, since March, 152016 a troop pullout should be realized ${ }^{5}$. However, it very quickly emerged that the action that followed these statements was completely a far cry from what had already been said. Thus on March $19^{\text {th }}$, the Russian air forces massively bombed the cities of Raqqa and Palmira ${ }^{6}$. Later on, instead of their troop pullout, at the end of October 2016 Russia redeployed an aircraft carrier group to the Mediterranean Sea in order to support their military contingent in the Middle East?

4 Д. Казанський. «Плівки Глазьєва». Як Росія намагалася підпалити схід та південь України, http://glavcom.ua/columns/denyskazanskiy/plivki-glazjeva-yak-rosiya-namagalasya-pidpaliti-shidta-pivden-ukrajini-368898.html, access: 25.08.2016.

5 Россия выводит войска из Сирии, http://news.liga.net/news/world/9549370-rossiya_vyvodit_ voyska_iz_sirii.htm, access: 14.03.2016.

6 Хронологія військових злочинів Росії в Сирї, http://russiakills.com/ua/syria, access: 19.03.2016.

7 Столтенберг стурбований переміщенням авіаносної групи РФ в Середземне море: удари по Алеппо можуть посилитися, http://www.unian.ua/world/1582767-stoltenberg-sturbovaniyperemischennyam-avianosnoji-grupi-rf-v-seredzemne-more-udari-po-aleppo-mojut-posilitisya. html, access: 20.10.2016. 
Another prominent example is the situation connected with the ceasefire in Syria. On September 10th, 2016 after 14 hours of negotiations, the Minister of Foreign Affairs of the Russian Federation Sergey Lavrov and United States Secretary of State John Kerry reached an agreement on a ceasefire beginning September 12th in Syria. After negotiations Sergey Lavrov noticed that the Syrian authorities reviewed the Russian-American plan and they were ready to fulfill it ${ }^{8}$. At the same time, on September 19th the Russian air forces or militaries of Bashar al-Assad with active support of Russia destroyed a humanitarian convoy of OON and the Red Crescent in Aleppo Province?

Sometimes in order to strengthen its international influence and weaken their rivals, the Russians combined in a more complicated way. The Russians' bombing in Syria caused huge floats of refugees ${ }^{10}$. At the same time the Kremlin actively supports the right-wing political forces in the European countries. Recently their influence has grown rapidly, last but not least due to the growing discontent regarding the floats of refugees in major countries of the EU. It seems like hard-right forces should treat Russia in a negative light, because the actions of the Russian military caused unfavorable changes. However, the situation was quite the opposite in practice. The relevant political forces actively cooperated with the Russian Federation; they received from the Kremlin moral and most likely economic support and came out with initiatives which oppose the democratic interests of the European Union. These arrangements consistently strengthen the position of Putin at the same time weakening the $\mathrm{EU}^{11}$.

Sometimes in order to justify their actions, the Kremlin leadership has referred to supposedly achieved oral agreements in the past. In particular, on April 17th, 2014 during his speech Vladimir Putin described the motives which prompted the Russians to capture Crimea. Among other things, he mentioned that during negotiations regarding the reunification of Germany NATO leaders gave assurances to the Soviet Union

${ }^{8}$ Керрі і Лавров домовилися про припинення вогню в Сиріï, https://www.ukrinform.ua/ rubric-abroad/2080689-kerri-i-lavrov-domovilisa-pro-pripinenna-vognu-v-sirii.html, access: 10.09.2016; США та Росія домовилися про перемир'я в Сиріï, http://www.bbc.com/ukrainian/ politics/2016/09/160910_syria_kerry_lavrov_sx, access: 10.09.2016.

9 США: удар по гуманітарному конвою ООН в Сиріі завдали російські літаки, https://www. dilovyi.info/ssha-udar-po-gumanitarnomu-konvoyu-oon-v-syriyi-zavdaly-rosijski-litaky/, access: 21.09.2016; Як Росія розбомбила перемир'я в Сиріï, http://espreso.tv/article/2016/09/20/rosiyski_ bomby_moskvu_zvynuvatyly_u_kryvavomu_viyskovomu_zlochyni_v_syriyi, access: 20.09.2016.

10 «Вихід» російських військ із Сирії: иим варто перейматись Україні, https://www.ukrinform.ua/ rubric-politycs/1982935-vihid-rosijskih-vijsk-iz-sirii-cim-varto-perejmatis-ukraini.html, access: 16.03.2016; Російські авіаудари в Сирії провокують зростання потоку біженців, http://www. nrcu.gov.ua/news.html?newsID=17974, access: 5.02.2016.

11 Європейські ультраправі на службі Путіна, http://molotoff.info/texts/27-2009-09-16-18-4939/6485-\%D1\%94vropejski-ultrapravi-na-sluzhbi-putina.html, access: 7.04.2014; 3ростання впливу праворадикалів у Європі як дестабілізуючий фактор єдності ЄC, http://www.ukrpolitic. com/?p=13855\&lang=ru, access: 7.11.2016. 
that the Alliance would not expand eastward ${ }^{12}$. However, the direct participants of the relevant negotiations, especially the last Soviet President Mikhail Gorbachev emphasized that NATO promises were myths and that this issue, in principle, could not be considered because at that time the Warsaw Pact was effective ${ }^{13}$. Representatives of the U.S. and Germany at different times came out with the denial of such statements ${ }^{14}$.

Such manipulations by authorities of the Russian Federation consistently caused concerns and counter-moves by the key international players. It should be noted that during the last time the European Union handled it quite clearly and objectively. For example, in May of 2015 the Committee on Foreign Affairs of the European Parliament adopted a resolution for the allocation of funds to fight against Russian propaganda. According to the resolution, the EU members were recommended to refrain from bilateral contacts with the Russian Federation and to increase joint efforts to counteract the aggressive policy of Kremlin. Brussels planned to implement a number of projects, including the establishment of Russian-language outlets, in order to fight against Russian propaganda and disinformation in the EU and beyond. The EU aimed to continue to support civil society in the form of Russian human rights activists, bloggers, independent media, academic staff and non-governmental organizations ${ }^{15}$.

Another response to the activities of the Russian Federation was the resolution called the "Strategic Communications of EU as Counteraction of Propaganda of Third Parties" adopted by the European Parliament in November 2016. The resolution stressed that the propaganda carried out by Russia is a part of "hybrid warfare" and it is intended to "distort the truth; to raise doubts and discord between the countries of union; to weaken the strategic unity of the EU and its North-American partners; to paralyze the decision-making process and to discredit the reputation of the EU and the transatlantic partnership"16.

In December 2016 there was a meeting between the foreign ministers of EU member states and NATO. According to the results of these talks, the European Council President Donald Tusk, European Commission President Jean-Claude Juncker and NATO Secretary General Jens Stoltenberg signed a joint declaration. According to the document, within the framework of the European Union and NATO interaction on

12 Страха перед НАТО у нас нет, но нас вынуждают к ответным действиям: Путин https:// regnum.ru/news/polit/1792376.html\#ixzz3IY9evj9Q, access: 17.04.2014.

13 Горбачов спростував Путіна: НАТО не обіияло не розширюватися. Це - міф, http://www. eurointegration.com.ua/news/2014/11/9/7027580/, access: 9.11.2014.

14 НАТО не обіияло РФ заморозити розширення на Схід - Кондоліза Райс, http://www. eurointegration.com.ua/news/2016/03/14/7046158/, access: 14.03.2016.

15 С. Косяков, ЕС начал поиск средств для борьбы с российской пропагандой, http://www.dw.com/ ru/ec-начал-поиск-средств-для-борьбы-с-российской-пропагандой/a-18446244, access: 12.05.2015.

16 Європарламент ухвалив резолюиію з протидї ворожій пропаганді Росї̈, http://tsn.ua/svit/ yevroparlament-uhvaliv-rezolyuciyu-z-protidiyi-vorozhiy-propagandi-rosiyi-811789.html, access: 23.11.2016. 
cyber security, crisis prevention and strategic communications, the European Centre for Combating Hybrid Threats will be established in $2017^{17}$.

Some EU members tried to complement the common European initiatives targeted at counteracting Russian information influence at the national level. In particular, the Center for Combating Terrorism and Hybrid Threats was announced to be created in the Czech Republic since January 1st, 2017. The institution will operate under the Interior Ministry of the Czech Republic and along with the other activities will be aimed at countering Russian propaganda and misinformation ${ }^{18}$.

Thus, it can be clearly stated that an aggressive information policy by the Russian Federation, especially in the framework of solving the "Ukrainian Issue" by the Kremlin, forces European leaders to resort to protective steps in response ${ }^{19}$.

\section{The Myth about "Neo-Nazis" and "Banderists" in Ukraine's Government}

Without any doubt, Ukraine is the greatest victim of Russian propaganda. It is currently focused on the maximum blocking of the western vector of foreign policy of Ukraine, discrediting it as a state, while increasing the "fatigue" of Ukraine in Europe and worldwide. The strategic objectives of the Russian Federation include the elimination of Ukraine as a state or its subordination once again to the Kremlin. In such circumstances, it is extremely important to demolish all the Russian myths about Ukraine and to spread the truth about the Russian role in the events that took place in Crimea in February - March 2014 and in the Donbass region since April 2014 up to this day.

Sometimes veiled or outright lies have been disproved, even by Russian leaders themselves. However, despite this, Russian propaganda quite often finds fertile ground in the minds of ordinary citizens of Europe. In February 2016 there was a meeting of the Subcommittee on Security and Defense of the European Parliament, during which the information war pursued by Russia was discussed. During the meeting the Head of the SWAT teams in media of the External Service of the European Union, Gill Portman, stressed that appropriate measures which are conducted by Russia against Ukraine and

17 ЕС и НАТО создадут изентр противодействия гибридным угрозам, http://112.ua/mir/es-i-natosozdadut-centr-protivodeystviya-gibridnym-ugrozam-357634.html, access: 7.12.2016; HATO ma ЄC створять иентр протидії гібридним загрозам, http://www.bbc.com/ukrainian/news-38229661, access: 6.12.2016.

18 Чехія посилить боротьбу з російською пропагандою, https://www.ukrinform.ua/rubricabroad/2148367-cehia-posilit-borotbu-z-rosijskou-propagandou.html, access: 29.12.2016.

19 Європарламент ухвалив резолюиію з протидії ворожій пропаганді Росї̈, http://tsn.ua/svit/ yevroparlament-uhvaliv-rezolyuciyu-z-protidiyi-vorozhiy-propagandi-rosiyi-811789.html, access: 23.11.2016; Інформаційна війна РФ проти України досягає результатів: В ЄС заявили про збільшення кількості симпатиків Кремля, http://www.unian.ua/society/1269099-informatsiynaviyna-rf-proti-ukrajini-dosyagla-rezultativ-v-es-zayavili-pro-zbilshennya-kilkosti-simpatikivkremlya.html, access: 18.02.2016; С. Косяков, ЕС начал поиск средств для борьбы с российской пропагандой, http://www.dw.com/ru/ec-начал-поиск-средств-для-борьбы-с-российской-пропагандой/a-18446244, access: 12.05.2015. 
the EU, bring real results - in the EU a number of those who sympathize with Russia and blame Kyiv for the war in the east is growing ${ }^{20}$.

This state of affairs is the natural consequence of the fundamental and multi-layered and biased information by the Russian Federation, trying to "make the best of a bad bargain." Russia spends enormous financial resources in order to discredit Ukraine on the international arena; to conceal its war crimes; to submit itself as a foreign entity that has played and continues to play only moderating and constructive role in the events in Crimea and Donbas, and generally to create a positive image of the Russian state in the world. From the estimates of experts, Russian taxpayers annually spend billions of US dollars on publicity campaigns by the Kremlin ${ }^{21}$.

Based on the information presented above, the important task of Ukrainian diplomats, politicians, scholars, journalists and experts lies in using all the opportunities to disclose false and deliberately distorted information by the Russian propaganda machine about what actually has been happening in Ukraine in recent years and what, in fact, Russia's role in these processes has been so far.

The leadership of the Russian Federation has repeatedly emphasized that Russia interfered with Ukrainian affairs because "neo-Nazis", "extreme nationalists" and "Banderists" came to power in Ukraine ${ }^{22}$. On March 18th, 2014 before signing a fictitious treaty joining Crimea and Sevastopol to the Russian Federation, Vladimir Putin made a speech before the Federal Assembly and commented on the reasons for such a bellicose move. Among other things, he hypocritically said: "We have always supported the territorial integrity of Ukraine... Do not believe those who scare you by Russia, shouting that after Crimea other regions will be seized. We do not want the partition of Ukraine, we do not need it. Crimea will remain to be a home for the representatives of all the nations who reside there. But it will never belong to the Banderists"23.

Slightly extending away from this string of logic, however, giving information of the binding key topics, let me cite some other words of Vladimir Putin which he uttered in August 2008. Shortly after the conflict with Georgia he gave an interview to the German television channel ARD TV. During the conversation, journalist Thomas

20 Інформаційна війна РФ проти Украйни досягає результатів: В ЄС заявили про збільшення кількості симпатиків Кремля, http://www.unian.ua/society/1269099-informatsiyna-viyna-rfproti-ukrajini-dosyagla-rezultativ-v-es-zayavili-pro-zbilshennya-kilkosti-simpatikiv-kremlya.html, access: 18.02.2016.

21 Русские пришли-2. Сколько стоит российская информационная война? http://sprotyv.info/ $\mathrm{ru} /$ news/kiev/russkie-prishli-2-skolko-stoit-rossiyskaya-informacionnaya-voyna?_utl_t=fb, access: 4.11.2015; Кремль витрачає на брехливу пропаганду мільярди доларів, http://na.mil.gov. ua/26458-kreml-vitrachaye-na-brexlivu-propagandu-milyardi-dolariv, access: 12.11.2015.

22 Путин: Крым никогда не будет бандеровским, http://vz.ru/news/2014/3/18/677740.html, access: 18.03.2014; Путин назвал украинцев "бандеровиами" и рассказал об аннексии Крыма, http:// ru.tsn.ua/politika/putin-nazval-ukraincev-banderovcami-i-rasskazal-ob-anneksii-kryma-422588. html, access: 26.04.2015.

23 Подписан договор о принятии Крыма и Севастополя в состав России, https://ria.ru/ politics/20140318/999999538.html, access: 18.03.2014. 
Roth, referring to the statements of French Foreign Minister Bernard Kouchner (years 2007-2010), asked whether Crimea and Sevastopol would be the next targets of the Kremlin. In response, Putin initially said that the issue is wrong and is provocative in nature. Then the Prime Minister of the Russian Federation stressed, "The Crimea is not a disputed territory... Russia has long recognized the borders of today's Ukraine. By and large, we have completed our talks on the border. Now we have to deal with the demarcation, but this is a technical issue... There are complicated processes going on in society in the Crimea. There are problems of the Crimean Tatars, the Ukrainian population, the Russian population, the Slavic population in general, but this is Ukraine's domestic political problem..." ${ }^{24}$.

Such rhetoric of Russian leadership remained even after the presidential and parliamentary elections in Ukraine in 2014, the results of which have been recognized by the whole world. In April 2015 there appeared a documentary entitled "The President", which summed up 15 years of Vladimir Putin's being in power. As part of one of the interviews for the film, the Kremlin leader gave his interpretation of the events in Crimea and stated: "If people want to come back to Russia and do not want to be ruled by neo-Nazis, extreme nationalists and Banderists, we have no right to abandon them" ${ }^{25}$.

Proposed clichés by the leadership of the Russian Federation are actively spreading through the Russian media and are used by Russian diplomats during various international forums ${ }^{26}$.

It would seem that the primitive manipulation with clichés and substitution of concepts in modern conditions, when the average citizen has virtually unlimited access to information resources is doomed to fail. However, the Russian Federation leadership managed to create a very efficient system that can substantially influence the public opinion not only within the country but also abroad.

Analyzing this component of Russian propaganda, we consider it necessary to represent our vision whether the Russian leadership has a reason to consider current ruling elites of Ukraine as Nazi followers; to analyze briefly the cooperation of the Ukrainian

24 Russian Prime Minister Vladimir Putin interviewed by the German ARD TV channel, http://archive. premier.gov.ru/eng/events/news/1758/, access: 29.08.2008.

25 "Президент". Фильм Владимира Соловьева, https://www.youtube.com/watch?v=HyNcbVuDJyA, access: 25.04.2015; Путин назвал украинцев “бандеровиами” и рассказал об аннексии Крымa, http://ru.tsn.ua/politika/putin-nazval-ukraincev-banderovcami-i-rasskazal-ob-anneksiikryma-422588.html, access: 26.04.2015.

26 Т. Назаренко, Фантомне військо. Як Україна протистоїть російській пропагандi, http://tsn. ua/ukrayina/fantomne-viysko-443418.html, access: 22.06.2015; Украинские захватчики, бандеровцы-нацисты и хунта: Чуркина опять «прорвало» в Совбезе ООН. Видеобакт, http:// www.bbcccnn.com.ua/podiyi/ukraynskye-zahvatchyky-banderovtsy-natsysty-y-hunta-churkynaopyat-prorvalo-v-sovbeze-oon-vydeofakt/, access: 11.12.2015; Foreign Minister Sergey Lavrov delivers a speech and answers questions during debates at the 51st Munich Security Conference, Munich, February 7, 2015, http://www.mid.ru/ru/press_service/minister_speeches/-/asset_publisher/7OvQR5KJWVmR/content/id/949358?p_p_id=101_INSTANCE_7OvQR5KJWVmR\&_101_INSTANCE_7OvQR5KJWVmR_languageId=en_GB, access: 7.02.2015. 
nationalist underground led by Stepan Bandera with Hitler's Germany and finally to show how the Nazis are treated in contemporary Russia.

First, it should be emphasized that after Viktor Yanukovych `s escape from Ukraine there were no new people among the Ukrainian leadership. In February 2014, the new Chairman of the Verkhovna Rada of Ukraine and the Acting President of Ukraine was one of the leaders of the All-Ukrainian Association "Batkivshchyna" with Oleksandr Turchynov. During the Soviet era Turchynov was the leader of Komsomol in Dnipropetrovsk region and a party official. During the period of independence he was repeatedly elected as a Member of Parliament; he held appointments for the Head of Security Service of Ukraine and was the First Deputy Prime Minister among other positions ${ }^{27}$. During the times of his previous political activity Oleksandr Turchynov was never identified with nationalist ideology, not to mention the neo-Nazism, by both his supporters and opponents.

A similar situation could be observed with Arseniy Yatsenyuk who was designated as Prime Minister of Ukraine in February 2014. Despite his relatively young age, since 2001 he had been working as the Minister of Economy in the Autonomous Republic of Crimea, the first deputy head of the National Bank of Ukraine, Minister of Economy, Foreign Minister and Chairman of the Verkhovna Rada of Ukraine. During this time he showed no sympathy for the right wing ideology, and what is more, he served as the Minister of Foreign Affairs of Ukraine (2007) at the time of premiership of pro-Russian and anti-national Viktor Yanukovych ${ }^{28}$.

On May 25th, 2015 elections of the president of Ukraine were held. Petro Poroshenko unprecedentedly won in all the electoral districts ${ }^{29}$ and he became the new president of Ukraine. Before leading the country, the fifth president of Ukraine was repeatedly elected to Parliament, he was Secretary of the National Security and Defense, Minister of Foreign Affairs and Minister of Economic Development and Trade of Ukraine. A conspicuous fact is that he held his last post in Mykola Azarov's government who was a member of the Party of Regions and during presidency of Viktor Yanukovych ${ }^{30}$. Therefore, Petro Poroshenko could not be blamed for being a consistent supporter of the nationalist ideology.

Thus, despite the unequivocal absence of sympathy for the members of the new leadership of Ukraine, the Kremlin's accusation of treating them as "neo-Nazis" and "Banderists" is incorrect.

27 Турчинов, Александр Валентинович, http://dosye.info/Турчинов,_Александр_Валентинович, access: 26.06.2015.

28 Яиенюк Арсений Петрович, http://file.liga.net/person/728-arsenii-yacenuk.html, access: 21.12.2016.

29 Підтримка вибориями кандидата на пост Президента України в регіоні. Пороменко Петро Олексійович, http://www.cvk.gov.ua/vp2014/wp302pt001f01=702pt021f01=134.html, access: 25.05.2014.

30 Пороченко Петр Алексеевич, http://file.liga.net/person/404-petr-poroshenko.html, access: 11.01.2017. 
Approaching this matter from another angle, it should be noted that among the parties which were the part of the Ukrainian parliament in 2014, the greatest commitment to nationalist ideas was declared by representatives of the All-Ukrainian Union "Svoboda." We can assume that the leaders of the Russian Federation referred these sentiments to them. However, there are some problems. During the presidential elections in Ukraine on May 25th, 2014, the leader of the All-Ukrainian Union "Svoboda" Oleh Tyahnybok managed to join the support of only $1.16 \%$ of voters who took part in the vote and came only tenth in the ranking ${ }^{31}$. Besides, his party during the parliamentary elections ${ }^{32}$ in November 2014 could not get into the Verkhovna Rada of Ukraine on party lists, because it had only $4.71 \%$ in the national multi-mandate constituency ${ }^{33}$. It is fair to point out that in 2012 at the time of Viktor Yanukovych's presidency the AllUkrainian Union "Svoboda" in a national multi-mandate constituency gained $10.44 \%$ of votes ${ }^{34}$. A low point in this situation was with the "Right Sector" which was formed in late November as a social movement and later it became political party of the nationalist wing and they played an important role at the time of the Revolution of Dignity. In the presidential elections of 2014 the leader of the "Right Sector" Dmytro Yarosh was supported by only $0.7 \%$ of voters ${ }^{35}$. However, during the parliamentary elections in the same year his party gained $1.8 \%$ of votes ${ }^{36}$.

In 1924 the famous Russian writer and diplomat Alexander Griboyedov wrote the comedy "Woe from Wit". It is written in aphoristic language and full of phraseology. One of the most famous lines is: "And who is to judge?"37. Following the logic of the talented Russian artist, we consider it necessary to show the attitude in Russia towards "nazism", "fascism" and radical nationalism.

31 Позачергові вибори Президента України 25 травня 2014 року, http://www.cvk.gov.ua/vp2014/ wp300pt001f01=702.html, access: 25.05.2014.

32 Currently, elections to the Verkhovna Rada of Ukraine are carried out under mixed system. 225 of the People's Deputies are chosen by a proportional representation in a national multi-member constituency under the party lists, another 225 - under the majority system in single member constituencies. The measure of the political forces support from the voters are its support in course of voting on a proportional basis.

33 Протокол Центральної виборчої комісії "Про результати виборів народних депутатів України у загальнодержавному багатомандатному виборчому окрузі", 26 жовтня 2014 року, http:// www.cvk.gov.ua/info/protokol_bmvo_ndu_26102014.pdf, access: 10.11.2014.

34 Протокол Центральної виборчої комісії “Про результати виборів народних депутатів Украіни у загальнодержавному багатомандатному виборчому окрузі", 28 жовтня 2012 року, http:// www.cvk.gov.ua/info/zbvo_2012.pdf, access: 10.11.2012.

35 Позачергові вибори Президента України 25 травня 2014 року, http://www.cvk.gov.ua/vp2014/ wp300pt001f01=702.html, access: 25.05.2014.

36 Протокол Центральної виборчої комісії "Про результати виборів народних депутатів України у загальнодержавному багатомандатному виборчому окрузі", 26 жовтня 2014 року, http:// www.cvk.gov.ua/info/protokol_bmvo_ndu_26102014.pdf, access: 10.11.2014.

37 А судьи кто? http://yznai-ka.ru/publ/quot_a_quot/a_sudi_kto/1-1-0-18, access: 20.05.2012. 
In fact, in Moscow at Leningradsky Prospekt, 75 people are in the All Saints Temple. During 1994-2007 there was a monument erected to commemorate the "Leaders of the White Movement and Cossack Chieftains". On the monument there was a listing of chieftains' names including Peter Krasnov, Andrey Shkuro, Timofey Domonov, Kelech Sultan Giray, Sergei Pavlov, Helmuth von Pannvits, Ivan Kononov, Viktor Zborowski and eight generals. Below their names it is stated: "To the Warriors of Rus Combined Union, Russian Corps, Cossack State, Cossacks of 15 Cavalry Corps who died for their faith and Motherland". It is interesting that the full name of that military formation sounded like "XV Cavalry Corps of SS". These persons while being in service for the Nazis, formed cavalry Cossack parts for the Wehrmacht during the Second World War. They fought on the territories of Belarus, Poland ${ }^{38}$ and Yugoslavia and were known for their peculiar cruelty. At the final stage of the Second World War, most of them were captured by the Western Allies, extradited to the Soviet Union and in 1947 executed by hanging. It is interesting that in 2003 and 2004 that was during the first presidential term of Vladimir Putin, Russian left-wing organizations demanded the demolition of the monument, but the Veterans Affairs Committee in RF State Duma along with prosecutors were in support of it. Only in 2007 the monument was destroyed by unknown persons $\mathrm{s}^{39}$.

The above-mentioned case had some continuation. In January 2008, the Don Cossacks chieftain and the State Duma deputy from the "United Russia" ${ }^{40}$ Victor Vodolatskyy initiated the creation of the working group for the rehabilitation of mentioned Petro Krasnov ${ }^{41}$. Instead, we know that during World War II, Krasnov was referring to Nazi Germany as an ally and patron, and the Germans as "the only healthy nation." The words "May God help German weapons and Hitler" also belong to him ${ }^{42}$. However soon, under the "influence of the society", and first of all, governor of Rostov region Volodymyr Chub, the board of the Don Cossacks chieftains recognized the incorrectness of their initiative ${ }^{43}$.

An equally interesting event occurred in summer 2016 in St. Petersburg. In particular, on June 16th, on the pane of the Military Academy of Logistics located on

38 They also participated in the suppression of the Warsaw Uprising.

39 И. Васюнин, История не рассудит, а люди могуm, http://2005.novayagazeta.ru/nomer/2005/66n/ n66n-s09.shtml, access: 8.09.2005; И. Васюнин, «Примирение народов» завериилось панихидой сучастием гитлеровиев, http://scepsis.net/library/id_1225.html, access: 12.05.2007; А. Кузнецов, Попьтка реабилитации атамана Краснова, http://alternathistory.com/popytka-reabilitatsiiatamana-krasnova, access: 3.05.2014; Памятник нацистам в Москве, http://scepsis.net/library/ id_1400.html, access: 3.02.2006.

40 Leading political party of Russian Federation under control of Kremlin administration.

${ }_{41}$ Донские казаки выступили за реабилитацию атамана Краснова http://web.archive.org/ web/20090924163525/http://www.mk.ru/59406/59406.html, access: 21.01.2008.

42 А. Кузнецов, Попьтка реабилитации атамана Краснова, http://alternathistory.com/popytkareabilitatsii-atamana-krasnova, access: 3.05.2014.

43 Генерал атаманам уже не люб, http://www.ng.ru/regions/2008-01-31/7_krasnov.html, access: 31.01.2008. 
Zakharievska Street, there was a memorial tablet installed to commemorate the Finnish military leader and President of Finland Carl Gustaf Mannerheim. The head of the Administration of Russia, President Serhii Ivanov and Minister of Culture Vladimir Medinskyi ${ }^{44}$ participated in the inauguration. Moreover, before the opening, Dmitrii Peskov, the Russian President's spokesman mentioned that “...till this time the identity of Mannerheim evokes hot debates, but one can definitely say that his personality is outstanding and is related to our history.... It is widely known that Carl Gustaf Mannerheim, born in the Russian Empire, is directly associated with the building where the memorial tablet was installed. However, it is also known that he led the Finnish troops against the Red Army in the war of 1939 - 1940. Then, the USSR lost about 170 thousand people. Similarly, Mannerheim, as Hitler's ally, participated in the military advance on the Soviet territory, for which he was awarded the fascist Knight and Iron Cross ${ }^{45}$.

Turning now to Ukraine, I would like to present a few facts about Stepan Bandera. The Russian leaders refer in general to the government representatives of the Ukrainian elite as his followers. It should be noted that even in recent years the attitude to one of the OUN organizers, Stepan Bandera, in Ukraine has been quite controversial. Some Ukrainians consider him as a national hero who led the military formation and fought for Ukraine's independence during World War II. Others interpret his personality exclusively in a negative way. In this study, we are not focusing on a broad analysis of his activity and the nationalist underground managed by him. Instead, let us limit this discussion to the number of well-known historic facts. At the beginning of World War II, the Ukrainian nationalists expected that the Nazis who were preparing for the war with the Soviet Union would agree to the establishment of an independent Ukrainian state. In this regard, they collaborated with the Germans. The cooperation lasted until the end of June 1941, when the representatives of the Ukrainian nationalist wing, subordinated to Bandera, declared the Act of Independence of Ukraine in Lviv. The Nazis rejected the act and started repressing the OUN members. From September 1941 to January 1942 Stepan Bandera was imprisoned by the Gestapo, and further, till September 1944 he was in the concentration camp in Sachsenhausen. It is also widely known that Stepan Bandera's brothers, Vasyl and Oleksandr, were tortured in the Auschwitz concentration

${ }^{44}$ Among the other things, when the public expressed dissatisfaction with the adjustment of the memorial tablet, minister Medinskyi responded with the following words: "There's no need to be holier than the Roman Pope and there's no need to be a bigger patriot than Joseph Vissarionovich Stalin who personally protected Mannerheim."

45 Д. Владимир, Россия уже окончательно запуталась в собственном безумии, http://hyser. com.ua/community/rossiya-uzhe-okonchatelno-zaputalas-v-sobstvennom-bezumii-90666, access: 20.06.2016; Д. Попович, Маннергейм в Питере: какую ошибку совершил Путин, http://inosmi. $\mathrm{ru} /$ politic/20160621/236915797.html, access: 21.06.2016; В Петербурге установили мемориальную доску с именем Маннергейма, https://meduza.io/news/2016/06/16/v-peterburge-ustanovilimemorialnuyu-dosku-s-imenem-mannergeyma, access: 16.06.2016. 
camp in July 1942, the third brother Bohdan was shot in Kherson ${ }^{46}$ by the Gestapo, his wife's brother was killed in Lviv prison ${ }^{47}$ (Kraliuk, 2014; Posivnych, 2015).

Undoubtedly, Mannerheim's actions can be explained, however, in this situation the statements of the representatives of the Kremlin can be considered as a model of refined historical cynicism. In St. Petersburg, they inaugurate a memorial tablet to Hitler's ally, whose troops took part in the occupation of Leningrad when about 600 thousand people were killed ${ }^{48}$, and at the same time, they criticize some political forces in Ukraine for praising Bandera.

Concluding the consideration of this respective problem, I would like to cite a quote from an interview with the leader of the gang "Ghost" of the so-called "Luhansk People's Republic" Oleksii Mozhovyi from March 2015 responded to the question from a journalist about the struggle against "fascism," Mozhovyi, who in no case can't be suspected of sympathizing with the new Ukrainian government claimed: "My dear, there is no fascism. This is an anti-fascist movement. Well, you know, just like in computers, right? There is a virus and antivirus. The virus is created by one who creates antivirus. That's all business...." Interestingly, within two months after this interview, Mozhovyi and his six subordinates were killed near Luhansk. The facts indicate that the actual perpetrator of the crime could be the Russian special forces ${ }^{49}$.

Thus, we have a paradoxical situation when the establishment of the Russian Federation calls the Ukrainians "neo-Nazis" and "Bandera followers," drawing parallels with the above-mentioned Stepan Bandera. While in Moscow and St. Petersburg they raise the monuments to the highest-rank military commanders who fought alongside Hitler at the time when Bandera and real "Bandera followers" were imprisoned in a German prison.

\section{Russian Soldiers in the Context of the Annexation of Crimea and the Donbass}

The textbook example of how the rhetoric of the Russian leadership may sustain fundamental imperial transformations is the case with the participation of Russian military in annexation of Crimea and the Donbas conflict.

On March 4th, 2014, Vladimir Putin held a meeting with journalists, in the process of which he evaluated the events in Ukraine and disclosed the Russian role in

46 Possibly in Mykolaiv.

47 П. Кралюк, Бандера и Путин, https://day.kyiv.ua/ru/article/podrobnosti/bandera-i-putin, access: 26.03.2014; М. Посівнич, Степан Бандера у німецьких тюрмах і концтаборах, http://www. istpravda.com.ua/articles/2014/01/1/140665/, access: 1.01.2015.

48 Д. Попович, Маннергейм в Питере: какую очибку совершил Путин, http://inosmi.ru/ politic/20160621/236915797.html, access: 21.06.2016.

49 Ликвидация Мозгового: Плотницкий устранил конкурента. Какие последствия для террористов “ЛНР” и “ДНР”? http://censor.net.ua/resonance/337405/likvidatsiya_mozgovogo_ plotnitskiyi_ustranil_konkurenta_kakie_posledstviya_dlya_terroristov_lnr_i_dnr, access: 24.05.2015; Полевой командир Мозговой убит под Луганском, http://www.bbc.com/russian/ international/2015/05/150524_ukraine_mozgovoi_killed, access: 24.05.2015. 
those events. During the meeting, Putin was asked whether the persons blocking the Ukrainian troops in Crimea were Russian soldiers. He answered that those were the representatives of local self-defence units. He also claimed that the Russians did not participate in their training. And besides, responding to questions about the plans for Crimea, Putin mentioned that the issue of Crimea's annexation by Russia was not considered $^{50}$.

Gradually, there was an outline and tendency to display a greater engagement of the Russian army in the invasion of Crimea. In April 2014, the Russian President held a four-hour live question-and-answer session broadcast by the leading state-owned Russian channels. In the course of the meeting, Putin was asked whether "green men" operating in Crimea were Russian soldiers. He did not give a direct answer to the question, but noted that "... behind the self-defence forces of Crimea, of course, stood our soldiers. They were very correct in their actions, but as I said, they acted firmly and professionally"s1. Later, the Russian president took the liberty of revealing the situation more objectively. In particular, within half a year, in his interview with the German channel ARD, Vladimir Putin claimed that "... we have never made it a secret that our Armed Forces, to be honest, blocked the Armed Forces of Ukraine located in Crimea and not with the aim to compel someone to vote, as this is impossible to do, but it was done in order to prevent bloodshed..." 52 .

And fundamentally different information was made public by Vladimir Putin during the interview with Andrii Kondrashov for the docummentary "Crimea: Way to Motherland" ${ }^{3}$. Then, the leader of the Kremlin actually "opened all the cards." Recalling the meeting on the events in Ukraine, on the nights of February 22nd-23rd, 2014, he claimed: "And, leaving, to tell the truth, leaving before everyone has left, I told all my colleagues, there were four of them, that the situation in Ukraine turned in such a way that we had to begin work on the restitution of Crimea to Russia. Because we can not leave this territory and people who live there to the mercy of fate and place them under the ruling of nationalists. Also, he set certain tasks, told us what and how to do it..." ${ }^{\prime 4}$.

Thus, we can see that within the year Putin's rhetoric concerning the participation of Russian troops had changed diametrically. While in March 2014, it was said that Russian troops did not participate in the events in Crimea,only a year later, Putin admitted that the operation of the peninsula's occupation, which he controlled personally, started as far back as in February.

50 Владимир Путин ответил на вопросы журналистов о ситуаиии на Украине, http://kremlin. ru/events/president/news/20366, access: 4.03.2014.

51 Прямая линия с Владимиром Путиным, http://kremlin.ru/events/president/news/20796, access: 17.04.2014.

52 Интервью немеикому телеканалу ARD, http://kremlin.ru/events/president/news/47029, access: 17.11.2014.

53 Original name: “Крым. Путь на Родину”.

${ }_{54}$ Крым. Путь на Родину, https://russia.tv/brand/show/brand_id/59195/, access: 15.03.2015. 
It should be emphasized that it was not only military personnel of the Russian Federation that took part in the occupation of Crimea butalso other military units were involved in the conflict. It is known that in the middle of February 2014, Kuban Cossacks arrived to Crimea along with the representatives of Crimean "Berkut" later played the role of the Crimean "self-defense" unit mentioned by the Russian Presi$\operatorname{den}^{56}$. It is also acknowledged that Chechen fighters of battalion "Vostok" were noticed on the peninsula on March 5th ${ }^{57}$. Awarding the Medal of the Ministry of Defense of the Russian Federation "For Liberation of Crimea" to Chechen President Ramzan Kadyrov and Governor of Krasnodar Krai Oleksandr Tkachiev can be referred to as confirmation of the respective information and recognition of the role that these respective structures played in the annexation of Crimea ${ }^{58}$.

Using this opportunity, we would like to pay more attention to this medal. One can find its picture on the Internet and see the inscription on the reverse side "For Liberation of Crimea 20.02.2014-18.03.2014". Thus, the beginning of liberation of Crimea is dated February 20th, which is the time when Viktor Yanukovych was still staying in Kyiv and governing Ukraine. Also, it is necessary to emphasize that we are talking about the medal from the Ministry of Defense of Russian Federation ${ }^{59}$.

To describe the full picture of the Crimean occupation, I take the liberty of presenting the words of the retired officer of the Armed Forces of the Russian Federation, adviser to "Prime-Minister of the Autonomous Republic of Crimea" Serhii Aksionov, "Minister of Defense" of the so-called "Donetsk People's Republic" Ihor Ghirkin. After returning to Russia, in one of his interviews, he clearly stated that the representatives of the Crimean authorities remained loyal to the Kyiv government for some time, and "the required" decision they endorsed after use of physical enforcement ${ }^{60}$.

55 A special militia unit whose representatives supported the regime of Yanukovych during the Revolution of Dignity, and illegally used force, special measures and weapons against peaceful Ukrainian protesters.

56 Rosyjska operacja Krym - specnaz, najemnicy, Kozacy i Berkut, http://alexjones.pl/pl/aj/aj-swiat/ aj-gospodarka-swiatowa/item/25346-rosyjska-operacja-krym-specnaz-najemnicy-kozacy-i-berkut, access: 5.04.2014.

57 Czeczeński batalion „Wostok” przejąłbudynki administracji obwodowej w Doniecku, http://www.defence24.pl/news_czeczenski-batalion-wostok-przejal-budynki-administracji-obwodowej-w-doniecku, access: 5.06.2014; Генштаб Украины: В Крыму замечен чеченский батальон «Восток», http:// www.rosbalt.ru/ukraina/2014/03/05/1240559.html, access: 7.03.2014.

58 Кадыров получил медаль “За освобождение Крыма" http://censor.net.ua/news/288957/kadyrov_poluchil_medal_za_osvobojdenie_kryma, access: 10.06.2014; Кадырова и Ткачева наградили медалями «За освобождение Крыма», http://lenta.ru/news/2014/06/07/kadyrov/, access: 15.06.2014.

59 Эксперты назвали 12 фактов, как медаль «За возвращение Крыма» подставила РФ, http:// www.profi-forex.org/novosti-rossii/entry1008208512.html, access: 5.06.2014; Медаль «За возвращение Крыма», https://ru.wikipedia.org/wiki/Медаль_«За_возвращение_Крыма», access: 5.06.2014.

60 Стрелков признался, как на самом деле происходило «народное присоединение» Крыма $\kappa$ Poсcuu, http://kriminal.tv/news/strelkov-priznalsja-kak-na-samom-dele-proishodilo-narodnoe- 
In fact, a similar situation occurred with the role of the Russian troops on the territory of Donbass in eastern Ukraine. In April 2014, there was another live question-and-answer session with the Russian President. During the event, one of the presenters asked Vladimir Putin what he thought about the accusations of the West and Kyiv, according to which Russia stood behind the events in the eastern Ukraine by organizing and financing them. He also asked if there were any Russian military units on the territory of Donbass. In response, the Kremlin leader called such accusations nonsense and added that "There are no Russian troops, or special services, or trainers in eastern Ukraine..." ${ }^{\prime 1}$. In a similar manner, Vladimir Putin stated this at the next meeting that took place a year later. In response to the question of the Russian politician and journalist Iryna Khakamada, the Russian President mentioned: "And finally, the question whether our troops are present in Ukraine? I tell you directly and clearly: There are no Russian troops in Ukraine"62. By the end of 2015, the rhetoric of Russian leader changed somewhat. Thus, within a large press conference held by Putin in December, he emphasized: "We have never said that there are no people there working on certain issues, including the military sphere, but that does not mean that regular Russian troops are present there. Feel the difference"63.

In the context of the evaluation of the role of Russian troops on the territory of Donbass, the Russian President pronounced extremely important words at the international investment forum "Russia Invites" in October 2016. Answering the question of Congress ex-member Rick Boucher on US-Russian relations, Putin unexpectedly acknowledged the participation of the Russian army in the events in the East Ukraine. In particular, he mentioned: “... we had to, I want to emphasize it, had to protect the Russian-speaking population on the territory of the Donbass, had to respond to the aspirations of people living in Crimea to return it to the Russian Federation"64.

Thus, in the case of the Donbass, as well as in the case of Crimea, the presence of Russian troops was gradually becoming more obvious. Moreover, the statements that "were expanding" the presence of Russian army in East Ukraine were made by the Russian President within various information events.

Undoubtedly, this transformation of the leadership position is demonstrative of the Kremlin. It shows the methods of Russian propaganda and the true face of the Russian leadership. It is important, especially considering some global players who traditionally used to admire Putin, and despite his criminal steps, continue to maintain the usual

prisoedinenie-krima-k-rossii.html, access: 25.01.2015.

61 Прямая линия с Владимиром Путиным, http://kremlin.ru/events/president/news/20796, access: 17.04.2014.

62 Прямая линия с Владимиром Путиным, http://kremlin.ru/events/president/news/49261, access: 16.04.2015.

63 Больмая пресс-конференция Владимира Путина, http://kremlin.ru/events/president/news/50971, access: 17.12.2015.

64 Инвестиционный форум ВТБ Капитал «Россия зовёт!», http://kremlin.ru/events/president/ news/53077, access: 12.10.2016. 
diplomatic contacts with Russia. It should also be important to the political forces in different countries that maintain contacts with Moscow and are supported by Russia, as well as to the citizens who support these respective political forces.

In fact, the participation of Russian troops and their leading role in the events on the territory of the East Ukraine is obvious. Moreover, one can trace the stages of accumulation of Russian participation in the processes on the territory of Donbass.

In April 2014, the new Ukrainian government had lost control over most major cities of Donetsk and Luhansk districts ${ }^{65}$. The Kremlin in these processes was presented with a few, but well prepared subversive groups ${ }^{66}$ that have managed to organize the local pro-Russian activists against Kyiv. Surprisingly, Ihor Ghirkin spoke in a very interesting and open manner on this issue in November 2014. In his interview for the newspaper "Tomorrow," he clearly clarified the key role of his unit in the beginning of the aggression on the territory of Donbass: "But the trigger of the war was still pressed by me. If our squad did not cross the border, as a result, everything would be over, just like in Kharkov and Odessa. There would be several dozens of killed, burnt and arrested. And this would be the end of the story... But practically, the war machine was launched by our squad and it is still going on" ${ }^{16}$.

The above cited information is very valuable, since it was announced on the Russian channel, and furthermore, by one of the most prominent contemporary leaders of terrorists.

The new trends within the Russian aggression emerged in the end of May, 2014. After the presidential elections, the Ukrainian army had intensified its activity which became evident within the fight for the liberation of the Donetsk airport on May, $26^{68}$. At the same time, the number of Russian troops and weapons increased in the Donbass region. One can consider the words of the self-proclaimed "Prime-Minister of Donetsk People's Republic" Oleksandr Borodai as a proof of it when he said that within the mentioned airport operation 33 Russians were killed ${ }^{69}$. Such a situation was quite logical, as sending mercenaries to Ukraine from the Russian Federation was organized by Russians at the national level. There were Cossack organizations involved and military registration and enlistment offices that were recruiting volunteers and the Ministry of

65 К. Машовець, Хроніка війни на Донбасі: від мітингів до танків, http://mediarnbo.org/2014/10/18/ хроніка-війни-на-донбасі-від-мітингів/, access: 25.10.2014.

66 Вторгнення військ РФ на сході країни відбулося - джерела, http://www.pravda.com.ua/ news/2014/04/12/7022207/, access: 5.05.2014.

67 И. Яковенко, «Кто тыl, Стрелок?», http://risk-inform.ru/article_4894.html, access: 2.12.2014.

68 К. Машовець, Хроніка війни на Донбасі: від мітингів до танків, http://mediarnbo.org/2014/10/18/ хроніка-війни-на-донбасі-від-мітингів/, асcеss: 25.10.2014.

${ }^{69}$ W Doniecku zginęło 33 Rosjan. Po stronie rzadu „walcza najemnicy, którzy wrócili z Syrii”, http:// www.tvn24.pl/wiadomosci-ze-swiata,2/w-doniecku-zginelo-33-rosjan-po-stronie-rzadu-walcza -najemnicy-ktorzy-wrocili-z-syrii,433776.html, access: 5.06.2014; Ukraiński oficer: Co najmniej 200 zabitych terrorystów. Poddadza się albo zlikwidujemy wszystkich, http://www.tvn24.pl/wiadomosci-ze-swiata,2/ukrainski-oficer-co-najmniej-200-zabitych-terrorystow-poddadza-sie-albozlikwidujemy-wszystkich,432783.html, access: 5.06.2014. 
Defense was supplying weapons to militants; border control services were assisting in crossing the Ukrainian-Russian border, and also Federal Safety Service that was controlling everything that was happening ${ }^{70}$.

From June of the same year, the separatists, supported by Russian troops, began to take control of the Ukrainian-Russian border ${ }^{71}$. These actions opened the opportunities for the mass delivery of Russian mercenaries and military equipment to the Ukrainian territory. The newly elected President of Ukraine - Petro Poroshenko, was aware that the stabilization of the situation in the East without the assistance by other countries was not going to be possible. Therefore, he was determined to take full control over the Ukrainian-Russian border as the most urgent task for the Ukrainian army ${ }^{72}$.

After the first complex successes of the Ukrainian militaries at the turning point of June - July, and also a successful attack on Luhansk and Donetsk during the last week of July, the separatists found themselves facing the threat of complete defeat, as it was mentioned later by Ihor Ghirkin ${ }^{73}$. The response to this situation was the systematic shelling of the Ukrainian units that were trying to take control of the border with the Russian territor $y^{74}$. Another threatening factor was the concentration of 42,000 Russian army troops that was ready to open aggression at the Ukrainian-Russian border ${ }^{75}$.

Concurrently, the separatists and mercenaries started to get more and more weapons from Russia. It is known that in the end of July and the beginning of August they

70 W Doniecku zginęło 33 Rosjan. Po stronie rządu „walcza najemnicy, którzy wrócili z Syrii”, http:// www.tvn24.pl/wiadomosci-ze-swiata,2/w-doniecku-zginelo-33-rosjan-po-stronie-rzadu-walcza -najemnicy-ktorzy-wrocili-z-syrii,433776.html, access: 5.06.2014; Ukraiński oficer: Co najmniej 200 zabitych terrorystów. Poddadzą się albo zlikwidujemy wszystkich, http://www.tvn24.pl/wiadomosci-ze-swiata,2/ukrainski-oficer-co-najmniej-200-zabitych-terrorystow-poddadza-sie-albozlikwidujemy-wszystkich,432783.html, access: 5.06.2014.

71 A. Łomanowski, R. Szoszyn, Rosyjskie czołgi na Ukrainie, http://www.rp.pl/artykul/1117576.html, access: 15.06 .2014 .

72 Порошенко пообіияв узяти кордон під контроль, армія перейшла в контрнаступ, http://www. newsru.ua/ukraine/15jun2014/naobicav.html, access: 16.06.2014.

73 «Кто тыл, «Стрелок»?», http://zavtra.ru/content/view/kto-tyi-strelok/, access: 22.10.2014.

74 Ежесуточно российские военные осуществляют 3-5 артиллерийских обстрелов украинских позиций - СНБО, http://www.segodnya.ua/regions/donetsk/ezhesutochno-rossiyskie-voennyeosushchestvlyayut-3-5-artilleriyskih-obstrelov-ukrainskih-poziciy-snbo-540532.html, access: 1.08.2014; Россия бомбит Донбасс, http://www.donbassnews.info/news/201407000006.shtml, access: 30.07.2014; М. Верный. Госдеп США обнародовал доказательства обстрела войсками РФ территории Украинь, http://www.mk.ru/politics/2014/07/27/gosdep-ssha-obnarodovaldokazatelstva-obstrela-voyskami-rf-territorii-ukrainy.html, access: 30.07.2014; Американська розвідка офіиійно заявляє, щзо Росія веде обстріл України, http://pro-vincia.com.ua/novini/ news_podyi/13994-amerikanska-rozvdka-ofcyno-zayavlyaye-scho-rosya-vede-obstrl-ukrayini.html, access: 30.07 .2014 .

75 A. Wilk, W. Konończuk, Wojna ukraińsko-rosyjska pod szyldem operacji antyterrorystycznej, http:// www.osw.waw.pl/pl/publikacje/analizy/2014-08-06/wojna-ukrainsko-rosyjska-pod-szyldemoperacji-antyterrorystycznej, access: 24.08.2014. 
received a lot of heavy weapons, including 17 tanks $^{76}$. For comparison, it should be pointed out that in the beginning of July there were only 3 tanks in Sloviansk controlled by the most powerful terrorist group led by Ihor Ghirkin ${ }^{77}$. The supply of hi-technology weapons together with calculations became another innovation ${ }^{78}$. Among other things, exactly those steps on behalf of Russia resulted in the destruction of Malaysian Boeing 777 on July 17, 2014.

The increasing military activity from the Russian side did not lead to the expected results by the separatists and Kremlin. Although the Ukrainian militaries failed to take control over the border, the territory controlled by the militants decreased significantly, and the so-called "DNR" was separated from the "LNR" and divided into several parts, and the Ukrainian troops have actually surrounded Luhansk ${ }^{79}$. Under such circumstances, the Kremlin leadership used the open aggression strategy. On August 23, four battalion task groups of the regular Russian army entered the territory of Donbass ${ }^{80}$. As a result of their actions, the situation at the front changed radically: the Ukrainian troops lost control over large territories and incurred greater losses than those ones compared with several previous months ${ }^{81}$.

Later, the Kremlin began to restore order on the occupied territories of Donetsk and Luhansk. They were systematically liquidating the odious gang groups' leaders who had their own opinion and did not want to obey those leaders appointed by Russia of the so-called "DNR" and "LNR" 82 . Also, the Cossack military units that played a very important role during the first months of aggression gradually disappeared from Donbass. Incidentally, the Don Cossacks chieftain Nikolai Kozitsyn made multiple

76 A. Wilk, W. Konończuk, Wojna ukraińsko-rosyjska pod szyldem operacji antyterrorystycznej, http:// www.osw.waw.pl/pl/publikacje/analizy/2014-08-06/wojna-ukrainsko-rosyjska-pod-szyldemoperacji-antyterrorystycznej, access: 24.08.2014.

77 «Кто тыл, «Стрелок»?», http://zavtra.ru/content/view/kto-tyi-strelok/, access: 22.10.2014.

78 РФ начала перебрасывать в Украину боевые расчеты из числа российских военнослужащих, http://zn.ua/UKRAINE/rf-nachala-perebrasyvat-v-ukrainu-boevye-raschety-iz-chisla-rossiyskihvoennosluzhaschih-148893_.html, access: 18.07.2014.

79 К. Машовець, Хроніка війни на Донбасі: від мітингів до танків, http://mediarnbo.org/2014/10/18/ хроніка-війни-на-донбасі-від-мітингів/, access: 25.10.2014; «Кто ты, «Стрелок»?», http:// zavtra.ru/content/view/kto-tyi-strelok/, access: 22.10.2014.

80 Як російські війська 23 серпня заходили на Донбас http://tyzhden.ua/Society/126003, access: 25.12.2014; Проміжний звіт ТСК з розслідування трагічних подій під Іловайськом. Повний mексm, http://www.pravda.com.ua/articles/2014/10/20/7041381/view_print/, access: 22.10.2014.

${ }^{81}$ Kijów: $w$ Donbasie walcza cztery taktyczne grupy batalionowe armii Rosji, http://www.tvn24.pl/ wiadomosci-ze-swiata,2/kijow-w-donbasie-walcza-cztery-taktyczne-grupy-batalionowe-armiirosji,463816.html, access: 2.09.2014; К. Машовець, Хроніка війни на Донбасі: від мітингів до танків, http://mediarnbo.org/2014/10/18/хроніка-війни-на-донбасі-від-мітингів/, access: 25.10.2014.

82 Як Кремль і його "куратори" ліквідують непотрібних свідків. Хроніка вбивств ватажків бойовиків. ФОТОрепортаж, http://ua.censor.net.ua/photo_news/410903/yak_kreml_i_yiogo_ kuratory_likviduyut_nepotribnyh_svidkiv_hronika_vbyvstv_vatajkiv_boyiovykiv_fotoreportaj, access: 17.10.2016. 
statements that indicated that his troops were executing the orders coming from the Kremlin. In particular, in November 2014, in his interview to Russian BBC service he emphasized that he obeys "only Putin and God" ${ }^{33}$. A few months later, in his interview to "Hazeta.Ru" Kozitsyn declared the following: "Higher than me is only Our Lord, and President Putin... Today Putin says that our people live on the territory of Donbass, and we are not going to leave them alone. Me and my Cossacks will help our President in this endeavour" ${ }^{\prime 2}$.

As a result of diverse and systematic work on the territory of the Donbass, there were two army corps under the control of Russia; it was staffed with Russian mercenaries, local separatists and Russian soldiers. The number of them is traditionally estimated to be several thousand. For example, according to the data of the Ministry of Internal Affairs of Ukraine, there were 10,000 Russian career military men on the territory of Donbass at the end of 2016. The quantity of Russian troops is systematically changing within the rotation ${ }^{85}$. As a rule, they are not at the forefront of the conflict, but at the times part of important operations, such as, at Ilovaisk (August, 2014) or Debaltsevo (February, 2015) the major problems were solved by them. The command of military units was carried out by Russian officers ${ }^{86}$. Russia also undertook to supply terrorists with weapons. As of September 2016, the so-called "DNR" and "LNR" were armed with about 700 tanks, 1,200 armored combat vehicles, more than 1000 artillery systems and more than 300 multiple launch rocket systems ${ }^{87}$.

\section{Conclusion}

Russian "information aggression" supported by the Kremlin's significant resources is an essential destabilizing factor for the countries of Ukraine and the European Union. The threats associated with Russian propaganda have been repeatedly discussed at the European forums of the highest level. The EU response to the information threat on behalf of the Russian Federation was practical implementation of a series of strategic

83 Атаман Козицьн: я подчиняюсь только Путину и Богу, http://www.bbc.com/russian/ multimedia/2014/11/141112_v_ukraine_ataman_kozitsyn, access: 12.11.2014.

84 Атаман Николай Козицььн: «Надо мной только Господь Бог и Путин», http://rslovar.com/ content/атаман-николай-козицын-«надо-мной-только-господь-бог-и-путин», access: 26.07.15.

85 Війська РФ на Донбасі провели ротацію і отримали наказ продовжувати бої, - Шкіряк, https:// www.rbc.ua/ukr/news/voyska-rf-donbasse-proveli-rotatsiyu-poluchili-1482490997.html, access: 23.12.2016.

86 Боєиь «спеицризначення ДНР»: допомога Росії була вирішальною, http://ua.korrespondent. net/ukraine/politics/3497940-boiets-spetspryznachennia-dnr-dopomoha-rosii-bula-vyrishalnoui, access: 31.03.2015; В «армійські корпуси» ОРДЛО вербуються бомжі та безробітні в якості гарматного м'яса, http://zik.ua/news/2016/09/10/v_armiyski_korpusy_ordlo_verbuyutsya_bomzhi_ ta_bezrobitni_v_yakosti_851332, access: 10.09.2016.

87 Statement by the President of Ukraine during the General Debate of the 71st session of the United Nations General Assembly, http://www.president.gov.ua/en/news/vistup-prezidenta-ukrayini-petraporoshenka-na-zagalnih-deba-38237, access: 21.09.2016. 
documents adopted by the European Parliament and the decision to create the European Centre for Hybrid Threats Resistance together with NATO.

In the context of the hybrid war pursued by the Russian Federation, the information responses and threats are a fundamental threat to Ukraine. Hence, it is an extremely important task to debunk Russian myths, which are generated and dispersed by the Kremlin. Discrimination of the Ukrainian ruling elite and their identification as the Nazis was one of the most favorite tricks used by Russian propaganda. The analysis of the outlined problem clearly indicates that such accusations are deprived of any validity. Instead, we can state that numerous cases of praising persons who quite openly, and in addition, for a long time, used to collaborate with the Nazi regime in Russia and at the highest level.

A vivid example of information manipulation is the process of rhetorical presentation and the manipulation of information by Russia in relation to the occupation of Crimea and the imperialistic events on the territory of Donbass by the Russian side. Undoubtedly, from the very beginning the role of Kremlin was evident to the experts, and later to the reporters. Ukraine and the international community have much direct and indirect evidence of military crimes committed by the Russian side. Instead, it was important how it was presented as propaganda in Russia. In practice, playing the key role in both cases, the leadership of the Russian Federation initially rejected any participation in these conflicts. Gradually, their rhetoric has changed and as of now, based on the words of the Russian President; it is known that it was him who controlled the operation of the Crimean peninsula occupation. Also, in October 2016, Vladimir Putin openly recognized the presence of Russian military in the processes occurring in the east of Ukraine.

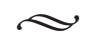

\begin{abstract}
This article analyzes informational manipulation by the Russian Federation authorities which are used for getting away with criminal activity in Ukraine; the strengthening of the Kremlin's authority on the international stage and the solution of foreign-policy tasks. Factual materials, which were studied while preparing this publication, gives reason to consider that Russian propaganda is destabilizing democracies and it constitutes a threat to the European continent. The article analyzes Russian manipulation connected with the use of such words as "neo-Nazi", "ultranationalists" and "Banderists" in relation to the new Ukrainian government authorities. The paper highlights the role of the Russian Federation and military in the process of the annexation of the Autonomous Republic of Crimea and the war in Donbass.
\end{abstract}

Keywords: the Russian Federation, manipulations, European Union, Ukraine, military aggression, propaganda 


\title{
Mity polityczne szerzone przez Rosyjską Federację na temat Ukrainy
}

Streszczenie: W artykule przeanalizowano manipulacje Federacji Rosyjskiej o charakterze informacyjnym, które są wykorzystywane do usprawiedliwienia działalności przestępczej na Ukrainie, wzmacniania autorytetu Kremla na arenie międzynarodowej, uprawiania polityki zagranicznej. Analizowany w trakcie przygotowania artykułu materiał faktologiczny daje podstawy do wniosku, że propaganda rosyjska jest obecnie istotnym czynnikiem destabilizującym, stwarzającym zagrożenie dla kontynentu europejskiego. Przeanalizowano przykłady manipulacji rosyjskiej, związane z używaniem przez nowe kierownictwo państwa ukraińskiego określeń: „neonazista”, „skrajny nacjonalista” i „banderowiec”, odzwierciedlono rolę przywództwa Rosji i rosyjskich żołnierzy w zajęciu terytorium Autonomicznej Republiki Krym i w czasie agresji na Donbasie.

Słowa kluczowe: Federacja Rosyjska, manipulacja, Unia Europejska, Ukraina, agresja wojenna, propaganda

\section{Политические мифы, распространяемые Российской Федерацией об Украине}

\begin{abstract}
Аннотация: В статье проанализированы манипуляции руководства Российской Федерации информационного характера, которые используются для оправдания преступной деятельности на Украине, усиление авторитета Кремля на международной арене, решения внешнеполитических задач. Фактологический материал, исследуемый в процессе подготовки публикации, дает основания для выводов, что российская пропаганда в настоящее время является существенным дестабилизирующим фактором, представляющим угрозу для европейского континента. Осуществлен анализ российских манипуляций, связанных с использованием в отношении нового украинского руководства терминов "неонацисты", "крайние националисты" и "бандеровцы", освещена роль руководства РФ и российских военных в процессе захвата территории Автономной республики Крым и агрессии на Донбассе.
\end{abstract}

Ключевые слова: Российская Федерация, манипуляции, Европейский Союз, Украина, военная агрессия, пропаганда

\section{Bibliography}

Czeczeński batalion „Wostok” przejąłbudynki administracji obwodowej w Doniecku, http://www.defence24. pl/news_czeczenski-batalion-wostok-przejal-budynki-administracji-obwodowej-w-doniecku, access: 5.06.2014.

Foreign Minister Sergey Lavrov delivers a speech and answers questions during debates at the 57st Munich Security Conference, Munich, February 7, 2015, http://www.mid.ru/ru/press_service/minister_speeches /-/asset_publisher/70vQR5KJWVmR/content/id/949358?p_p_id=101_INSTANCE_70vQR5KJ WVmR\&_101_INSTANCE_70vQR5KJWVmR_languageld=en_GB, access: 7.02.2015.

Kijów: w Donbasie walczą cztery taktyczne grupy batalionowe armii Rosji, http://www.tvn24.pl/wiadomoscize-swiata,2/kijow-w-donbasie-walcza-cztery-taktyczne-grupy-batalionowe-armii-rosji,463816.html, access: 2.09.2014.

Łomanowski A., Szoszyn R., Rosyjskie czołgi na Ukrainie, http://www.rp.pl/artykul/1117576.html, access: 15.06.2014. 
Rosyjska operacja Krym - specnaz, najemnicy, Kozacy i Berkut, http://alexjones.pl/pl/aj/aj-swiat/aj-gospodarka-swiatowa/item/25346-rosyjska-operacja-krym-specnaz-najemnicy-kozacy-i-berkut, access: 5.04.2014.

Russian Prime Minister Vladimir Putin interviewed by the German ARD TV channel, http://archive.premier. gov.ru/eng/events/news/1758/, access: 29.08.2008.

Statement by the President of Ukraine during the General Debate of the 71st session of the United Nations General Assembly, http://www.president.gov.ua/en/news/vistup-prezidenta-ukrayini-petra-poroshenka -na-zagalnih-deba-38237, access: 21.09.2016.

Ukraiński oficer: Co najmniej 200 zabitych terrorystów. Poddadzą się albo zlikwidujemy wszystkich, http:/l www.tvn24.pl/wiadomosci-ze-swiata,2/ukrainski-oficer-co-najmniej-200-zabitych-terrorystow-poddadza-sie-albo-zlikwidujemy-wszystkich,432783.html, access: 5.06.2014.

W Doniecku zginęło 33 Rosjan. Po stronie rządu "walczą najemnicy, którzy wrócili z Syrii", http://www.tvn24. pl/wiadomosci-ze-swiata,2/w-doniecku-zginelo-33-rosjan-po-stronie-rzadu-walcza-najemnicyktorzy-wrocili-z-syrii,433776.html, access: 5.06 .2014$.

Wilk A., Konończuk W., Wojna ukraińsko-rosyjska pod szyldem operacji antyterrorystycznej, http://www.osw. waw.pl/pl/publikacje/analizy/2014-08-06/wojna-ukrainsko-rosyjska-pod-szyldem-operacji-antyterrorystycznej, access: 24.08.2014.

Американська розвідка офіційно заявляє, що Росія веде обстріл України, http://pro-vincia.com.ua/novini/news_podyi/13994-amerikanska-rozvdka-ofcyno-zayavlyaye-scho-rosya-vede-obstrl-ukrayini. html, access: 30.07.2014.

А судьи кто? http://yznai-ka.ru/publ/quot_a_quot/a_sudi_kto/1-1-0-18, access: 20.05.2012.

Атаман Козицын: я подчиняюсь только Путину и Богу, http://www.bbc.com/russian/multimedia/2014/11/141112_v_ukraine_ataman_kozitsyn, access: 12.11.2014.

Атаман Николай Козицын: «Надо мной только Господь Бог и Путин», http://rslovar.com/content/ атаман-николай-козицын-«надо-мной-только-господь-бог-и-путин», асcess: 26.07.15.

Бисмарк о России и Украине, http://journal-otechestvo.ru/bismark-rossia-ukraina/, access: 6.08.2015.

Большая пресс-конференция Владимира Путина http://kremlin.ru/events/president/news/50971, access: 17.12.2015.

Боєць «спецпризначення ДНР»: допомога Росії була вирішальною, http://ua.korrespondent.net/ ukraine/politics/3497940-boiets-spetspryznachennia-dnr-dopomoha-rosii-bula-vyrishalnoui, access: 31.03.2015.

B «армійські корпуси» ОРДЛО вербуються бомжі та безробітні в якості гарматного м'яса, http://zik. ua/news/2016/09/10/v_armiyski_korpusy_ordlo_verbuyutsya_bomzhi_ta_bezrobitni_v_yakosti_851332, access: 10.09.2016.

Васюнин И., История не рассудит, а люди могут, http://2005.novayagazeta.ru/nomer/2005/66n/ n66n-s09.shtml, access: 8.09.2005.

Васюнин И., «Примирение народов» завершилось панихидой с участием гитлеровцев, http://scepsis. net/library/id_1225.html, access: 12.05.2007.

«Вихід» російських військ із Сирії: чим варто перейматись Україні, https://www.ukrinform.ua/rubricpolitycs/1982935-vihid-rosijskih-vijsk-iz-sirii-cim-varto-perejmatis-ukraini.html, access: 16.03.2016.

Війська РФ на Донбасі провели ротацію іотримали наказ продовжувати бої, - Шкіряк, https://www.rbc. ua/ukr/news/voyska-rf-donbasse-proveli-rotatsiyu-poluchili-1482490997.html, access: 23.12.2016. 
Владимир Путин ответил на вопросы журналистов о ситуации на Украине. http://kremlin.ru/events/ president/news/20366, access: 4.03.2014.

В Петербурге установили мемориальную доску с именем Маннергейма, https://meduza.io/news/ 2016/06/16/v-peterburge-ustanovili-memorialnuyu-dosku-s-imenem-mannergeyma, access: 16.06.2016.

Вторгнення військ РФ на сході країни відбулося - джерела, http://www.pravda.com.ua/news/2014 104/12/7022207/, access: 5.05.2014.

Генерал атаманам уже не люб, http://www.ng.ru/regions/2008-01-31/7_krasnov.html, access: 31.01.2008. Генштаб Украины: В Крыму замечен чеченский батальон «Восток», http://www.rosbalt.ru/ukraina/20 14/03/05/1240559.html, access: 7.03.2014.

Горбачов спростував Путіна: НАТО не обіцяло не розширюватися. Це - міф, http://www.eurointegration.com.ua/news/2014/11/9/7027580/, access: 9.11.2014.

Дедей В., Россия уже окончательно запуталась в собственном безумии, http://hyser.com.ua/community/rossiya-uzhe-okonchatelno-zaputalas-v-sobstvennom-bezumii-90666, access: 20.06.2016.

Донские казаки выступили за реабилитацию атамана Краснова, http://web.archive.org/web/2009092 4163525/http://www.mk.ru/59406/59406.html, access: 21.01.2008.

Ежесуточно российские военные осуществляют 3-5 артиллерийских обстрелов украинских позиций - СНБ0, http://www.segodnya.ua/regions/donetsk/ezhesutochno-rossiyskie-voennye-osushchestvlyayut-3-5-artilleriyskih-obstrelov-ukrainskih-poziciy-snbo-540532.html, access: 1.08.2014.

EC и НАTO создадут центр противодействия гибридным угрозам, http://112.ua/mir/es-i-nato-sozdadut-centr-protivodeystviya-gibridnym-ugrozam-357634.html, access: 7.12.2016.

Європарламент ухвалив резолюцію з протидії ворожій пропаганді Pociї, http://tsn.ua/svit/yevroparlament-uhvaliv-rezolyuciyu-z-protidiyi-vorozhiy-propagandi-rosiyi-811789.html, access: 23.11.2016.

Європейські ультраправі на службі Путіна, http://molotoff.info/texts/27-2009-09-16-18-49-39/6485\%D1\%94vropejski-ultrapravi-na-sluzhbi-putina.html, access: 7.04.2014.

Эксперты назвали 12 фактов, как медаль «За возвращение Крыма» подставила РФ, http://www. profi-forex.org/novosti-rossii/entry1008208512.html, access: 5.06.2014.

Зростання впливу праворадикалів у Європі як дестабілізуючий фактор єдності ЄC, http://www.ukrpolitic.com/?p=13855\&lang=ru, access: 7.11.2016.

Инвестиционный форум ВТБ Капитал «Россия зовёт!», http://kremlin.ru/events/president/news/53077, access: 12.10 .2016$.

Интервью немецкому телеканалу ARD, http://kremlin.ru/events/president/news/47029, access: 17.11.2014.

Інформаційна війна РФ проти України досягає результатів: В ЄС заявили про збільшення кількості симпатиків Кремля, http://www.unian.ua/society/1269099-informatsiyna-viyna-rf-proti-ukrajini -dosyagla-rezultativ-v-es-zayavili-pro-zbilshennya-kilkosti-simpatikiv-kremlya.html, access: 18.02.2016.

Кадыроваи Ткачеванаградилимедалями «ЗаосвобождениеКрыма», http://lenta.ru/news/2014/06/07/ kadyrov/, access: 15.06.2014.

Кадыров получил медаль "За освобождение Крыма" http://censor.net.ua/news/288957/kadyrov poluchil_medal_za_osvobojdenie_kryma, access: 10.06.2014.

Казанський Д., «Плівки Глазьєва». Як Росія намагалася підпалити схід та південь України, http:// glavcom.ua/columns/denyskazanskiy/plivki-glazjeva-yak-rosiya-namagalasya-pidpaliti-shid-tapivden-ukrajini-368898.html, access: 25.08.2016. 
Керрі і Лавров домовилися про припинення вогню в Сирії, https://www.ukrinform.ua/rubricabroad/2080689-kerri-i-lavrov-domovilisa-pro-pripinenna-vognu-v-sirii.html, access: 10.09.2016.

Косяков С., ЕС начал поиск средств для борьбы с российской пропагандой, http://www.dw.com/ru/ecначал-поиск-средств-для-борьбы-с-российской-пропагандой/a-18446244, access: 12.05.2015.

Кралюк П., Бандера и Путин, https://day.kyiv.ua/ru/article/podrobnosti/bandera-i-putin, access: 26.03.2014.

Кремль витрачає на брехливу пропаганду мільярди доларів, http://na.mil.gov.ua/26458-kremlvitrachaye-na-brexlivu-propagandu-milyardi-dolariv, access: 12.11.2015.

Крым. Путь на Родину, https://russia.tv/brand/show/brand_id/59195/, access: 15.03.2015.

«Кто ты, «Стрелок»?», http://zavtra.ru/content/view/kto-tyi-strelok/, access: 22.10.2014.

Кузнецов А. Попытка реабилитации атамана Краснова, http://alternathistory.com/popytka-reabilitatsiiatamana-krasnova, access: 3.05.2014.

Ликвидация Мозгового: Плотницкий устранил конкурента. Какие последствия для террористов "ЛНР" и "ДНР"? http://censor.net.ua/resonance/337405/likvidatsiya_mozgovogo_plotnitskiyi_ ustranil_konkurenta_kakie_posledstviya_dlya_terroristov_Inr_i_dnr, access: 24.05.2015.

Машовець К., Хроніка війни на Донбасі: від мітингів до танків, http://mediarnbo.org/2014/10/18/ хроніка-війни-на-донбасі-від-мітингів/, асcеss: 25.10.2014.

Медаль «За возвращение Крыма», https://ru.wikipedia.org/wiki/Медаль_«За_возвращение_Крыма», access: 5.06 .2014$.

Назаренко Т., Фантомне військо. Як Україна протистоїть російській пропаганді, http://tsn.ua/ukrayina/ fantomne-viysko-443418.html, access: 22.06.2015.

НАТО не обіцяло РФ заморозити розширення на Схід - Кондоліза Райс, http://www.eurointegration. com.ua/news/2016/03/14/7046158/, access: 14.03.2016.

НАTO та ЄС створять центр протидії гібридним загрозам, http://www.bbc.com/ukrainian/news38229661, access: 6.12.2016.

Памятник нацистам в Москве, http://scepsis.net/library/id_1400.html, access: 3.02.2006.

Підтримка виборцями кандидата на пост Президента України в регіоні. Порошенко Петро Олексійович, http://www.cvk.gov.ua/vp2014/wp302pt001f01=702pt021f01=134.html, access: 25.05.2014.

Подписан договор о принятии Крыма и Севастополя в состав России, https://ria.ru/politics/2014 0318/999999538.html, access: 18.03.2014.

Позачергові вибори Президента України 25 травня 2014 року, http://www.cvk.gov.ua/vp2014/ wp300pt001f01=702.html, access: 25.05.2014.

Полевой командир Мозговой убит под Луганском, http://www.bbc.com/russian/international/2015/05/ 150524_ukraine_mozgovoi_killed, access: 24.05.2015.

Попович Д., Маннергейм в Питере: какую ошибку совершил Путин, http://inosmi.ru/politic/2016 0621/236915797.html, access: 21.06.2016.

Порошенко Петр Алексеевич, http://file.liga.net/person/404-petr-poroshenko.html, access: 11.01.2017. Порошенко пообіцяв узяти кордон під контроль, армія перейшла в контрнаступ, http://www.newsru. ua/ukraine/15jun2014/naobicav.html, access: 16.06.2014.

Посівнич М., Степан Бандера у німецьких тюрмах і концтаборах, http://www.istpravda.com.ua/ articles/2014/01/1/140665/, access: 1.01.2015.

Правила життя Отто Бісмарка, http://www.jnsm.com.ua/cgi-bin/m/pz.pl?ps=13, access: 1.04.2016. 
"Президент". Фильм Владимира Соловьева, https://www.youtube.com/watch?v=HyNcbVuDJyA, access: 25.04.2015.

Проміжний звіт ТСК з розслідування трагічних подій під Іловайськом. Повний текст, http://www. pravda.com.ua/articles/2014/10/20/7041381/view_print/, access: 22.10.2014.

Протокол Центральної виборчої комісії "Про результати виборів народних депутатів України у загальнодержавному багатомандатному виборчому окрузі", 28 жовтня 2012 року, http://www.cvk. gov.ua/info/zbvo_2012.pdf, access: 10.11.2012.

Протокол Центральної виборчої комісії "Про результати виборів народних депутатів України у загальнодержавному багатомандатному виборчому окрузі", 26 жовтня 2014 року, http://www.cvk. gov.ua/info/protokol_bmvo_ndu_26102014.pdf, access: 10.11.2014.

Прямая линия с Владимиром Путиным, http://kremlin.ru/events/president/news/20796, access: 17.04.2014.

Прямая линия с Владимиром Путиным, http://kremlin.ru/events/president/news/49261, access: 16.04.2015.

Путин: Крым никогда не будет бандеровским, http://vz.ru/news/2014/3/18/677740.html, access: 18.03.2014.

Путин назвал украинцев "бандеровцами" и рассказал об аннексии Крыма, http://ru.tsn.ua/politika/putin-nazval-ukraincev-banderovcami-i-rasskazal-ob-anneksii-kryma-422588.html, access: 26.04.2015.

Російські авіаудари в Сирії провокують зростання потоку біженців, http://www.nrcu.gov.ua/news. html?newsID=17974, access: 5.02.2016.

Россия бомбит Донбасс, http://www.donbassnews.info/news/201407000006.shtml, 30.07.2014.

М. Верный. Госдеп США обнародовал доказательства обстрела войсками РФ территории Украины, http://www.mk.ru/politics/2014/07/27/gosdep-ssha-obnarodoval-dokazatelstva-obstrela-voyskami-rf-territorii-ukrainy.html, access: 30.07.2014.

Россия выводит войска из Сирии, http://news.liga.net/news/world/9549370-rossiya_vyvodit_voyska_ iz_sirii.htm, 14.03.2016.

Русские пришли-2. Сколько стоит российская информационная война? http://sprotyv.info/ru/news/ kiev/russkie-prishli-2-skolko-stoit-rossiyskaya-informacionnaya-voyna?_ut__t=fb, access: 4.11.2015.

РФ начала перебрасывать в Украину боевые расчеты из числа российских военнослужащих, http://zn.ua/UKRAINE/rf-nachala-perebrasyvat-v-ukrainu-boevye-raschety-iz-chisla-rossiyskihvoennosluzhaschih-148893_html, access: 18.07.2014.

Столтенберг стурбований переміщенням авіаносної групи РФ в Середземне море: удари по Алеппо можуть посилитися, http://www.unian.ua/world/1582767-stoltenberg-sturbovaniy-peremischennyam-avianosnoji-grupi-rf-v-seredzemne-more-udari-po-aleppo-mojut-posilitisya.html, access: 20.10.2016.

Страха перед НАТо у нас нет, но нас вынуждают к ответным действиям: Путин, https://regnum.ru/ news/polit/1792376.html\#ixzz3IY9evj9Q, access: 17.04.2014.

Стрелков признался, как на самом деле происходило «народное присоединение» Крыма к России, http://kriminal.tv/news/strelkov-priznalsja-kak-na-samom-dele-proishodilo-narodnoe-prisoedinenie -krima-k-rossii.html, access: 25.01.2015.

США та Росія домовилися про перемир'я в Сирії, http://www.bbc.com/ukrainian/politics/2016/ 09/160910_syria_kerry_lavrov_sx, access: 10.09.2016. 
Pobrane z czasopisma Wschód Europy http://journals.umcs.pl/we

Data: 26/04/2023 15:47:41

США: удар по гуманітарному конвою ООН в Сирії завдали російські літаки, https://www.dilovyi.info/ ssha-udar-po-gumanitarnomu-konvoyu-oon-v-syriyi-zavdaly-rosijski-litaky/, access: 21.09.2016.

Турчинов, Александр Валентинович, http://dosye.info/Турчинов,_Александр_Валентинович, аccess: 26.06.2015.

Украинские захватчики, бандеровцы-нацисты и хунта: Чуркина опять «прорвало» в Совбезе ООН.

Видеофакт, http://www.bbcccnn.com.ua/podiyi/ukraynskye-zahvatchyky-banderovtsy-natsysty-yhunta-churkyna-opyat-prorvalo-v-sovbeze-oon-vydeofakt/, access: 11.12.2015.

Хронологія військових злочинів Росії в Сирії, http://russiakills.com/ua/syria, access: 19.03.2016.

Чехія посилить боротьбу з російською пропагандою, https://www.ukrinform.ua/rubric-abroad/2148 367-cehia-posilit-borotbu-z-rosijskou-propagandou.html, access: 29.12.2016.

Як Росія розбомбила перемир'я в Сирії, http://espreso.tv/article/2016/09/20/rosiyski_bomby_moskvu_

zvynuvatyly_u_kryvavomu_viyskovomu_zlochyni_v_syriyi, access: 20.09.2016.

Як Кремль і його "куратори" ліквідують непотрібних свідків. Хроніка вбивств ватажків бойовиків. ФО-

ТОрепортаж, http://ua.censor.net.ua/photo_news/410903/yak_kreml_i_yiogo_kuratory_likviduyut_ nepotribnyh_svidkiv_hronika_vbyvstv_vatajkiv_boyiovykiv_fotoreportaj, access: 17.10.2016.

Яковенко И., «Кто ты, Стрелок?», http://risk-inform.ru/article_4894.html, access: 2.12.2014.

Як російські війська 23 серпня заходили на Донбас http://tyzhden.ua/Society/126003, access: 25.12.2014.

Яценюк Арсений Петрович, http://file.liga.net/person/728-arsenii-yacenuk.html, access: 21.12.2016. 